\title{
REGULASI PENANGGULANGAN BENCANA DI KABUPATEN KEDIRI
}

\author{
Prasetyo Isbandono \\ Jurusan Administrasi Publik, Fakultas Ilmu Sosial dan Hukum, Universitas Negeri Surabaya, \\ prasetyoisbandono@unesa.ac.id \\ Agus Prastyawan \\ Jurusan Administrasi Publik, Fakultas Ilmu Sosial dan Hukum, Universitas Negeri Surabaya, \\ agusprastyawan@unesa.ac.id
}

\begin{abstract}
Abstrak
Secara geografis Indonesia merupakan pertemuan empat lempeng tektonik, yaitu lempeng Benua Asia, Benua Australia, Samudera Hindia dan Samudera Pasifik. Bagian Selatan dan Timur terdapat sabuk vulkanik (volcanic arc) yang memanjang dari Pulau Sumatera-Jawa-Nusa Tenggara-Sulawesi, berupa pegunungan vulkanik. Kondisi tersebut berpotensi sekaligus rawan bencana seperti letusan gunung berapi, gempa bumi, tsunami, banjir dan tanah longsor. Data menunjukkan Indonesia merupakan salah satu negara dengan risiko gempa bumi yang tinggi di dunia, lebih dari 10 kali lipat risiko gempa bumi di Amerika Serikat (Arnold, 2014). Menurut Kepala Pelaksana Badan Penanggulangan Bencana Daerah Jawa Timur terdapat risiko bencana yang beragam dari gempa bumi, tsunami, longsor, banjir, kekeringan, puting beliung, kebakaran, letusan gunung berapi (Sudarmawan, 2014). Untuk itu perlunya dilakukan pembenahan penanggulangan bencana, baik regulasi yang menjadi dasar hukumnya maupun pengelolaan lembaga penanggulangan bencana dengan lebih profesional..
\end{abstract}

Kata Kunci: Regulasi, Penanggulangan bencana, Lembaga

\begin{abstract}
Geographically Indonesia is a meeting of four tectonic plates, namely the Asian Continent, the Australian Continent, the Indian Ocean and the Pacific Ocean. The South and East parts have volcanic arc extending from Sumatra-Java Island-Nusa Tenggara-Sulawesi, in the form of volcanic mountains. These conditions are potentially at the same time prone to disasters such as volcanic eruptions, earthquakes, tsunamis, floods and landslides. Data shows that Indonesia is one of the countries with high risk of earthquakes in the world, more than 10 times the risk of earthquakes in the United States (Arnold, 2014). According to the Chief Executive of the East Java Regional Disaster Management Agency there are various disaster risks from earthquakes, tsunamis, landslides, floods, droughts, tornadoes, fires, volcanic eruptions (Sudarmawan, 2014). For this reason, it is necessary to improve disaster management, both regulations that are the legal basis and management of disaster management institutions in a more professional manner.
\end{abstract}

Keywords: Regulation, Disaster Management, Institutions.

\section{PENDAHULUAN}

Pada kurun waktu belakangan ini, penanggulangan bencana secara umum telah mengalami perubahan paradigma yang amat mendasar, yaitu dari penanganan bencana (yang sifatnya responsif-kuratuf) berubah menjadi pengurangan risiko bencana (yang bersifat antisipatif-prefentif); artinya saat ini penyelenggaraan penanggulangan bencana lebih menitikberatkan pada tahap pra bencana daripada tahap tanggap darurat (Haryati, 2013). Undang-undang Nomor 24 tahun 2007 tentang Penanggulangan Bencana mendefinisikan bencana sebagai peristiwa atau rangkaian peristiwa yang mengancam dan mengganggu kehidupan dan penghidupan masyarakat.
Upaya penanggulangan bencana merupakan rangkaian kegiatan :(1) sejak sebelum terjadi bencana, yang disebut sebagai kegiatan pencegahan, mitigasi,kesiapsiagaan dalam menghadapi bencana; (2) kegiatan yang dilakukan pada saat terjadinya bencana atau yag disebut sebagai kegiatan tanggap darurat dan (3) kegiatan setelah terjadinya bencana yang berupa kegiatan pemulihan atau rehabilitasi dan rekonstruksi.

Kabupaten Kediri merupakan kabupaten yang memiliki wilayah yang luas di bandingkan wilayah lain di Propinsi Jawa Timur. Data astronomi menyebutkan Kabupaten Kediri memiliki luas 963,21 km2 yang terbagi dalam 26 kecamatan. Kabupaten Kediri memiliki gunung berapi dengan ketinggian 1.730 meter dari permukaan laut (mdpl) teraktif di Jawa Timur dan juga dikelilingi Sungai 
Brantas yaitu sungai terpanjang kedua di Pulau Jawa setelah sungai Bengawan Solo.

Kabupaten Kediri adalah salah satu kabupaten di Provinsi Jawa Timur, Indonesia. Posisi geografi Kabupaten Kediri terletak antara 111 o 47' 05" sampai dengan 112o 18'20" Bujur Timur dan 7o 36' 12" sampai dengan 8o 0' 32 Lintang Selatan.

Populasi penduduk Kabupaten Kediri pada Tahun 2014 sebanyak 1.492.585 jiwa, terdiri dari laki-laki sebanyak 755.628 jiwa dan perempuan 736.957 jiwa. Secara administrasi kabupaten Kediri terdiri dari 26 Kecamatan, meliputi 344 desa/kelurahan, 2.812 Rukun Warga (RW), dan 9.265 Rukun Tetangga (RT).

Kabupaten kediri merupakan salah satu kabupaten di Jawa Timur yang memiliki potensi terjadinya bencana alam, dan yang lebih menarik ternyata Kabupaten Kediri hingga akhir tahun 2014 belum memiliki BPBD (Badan Penanggulangan Bencana Daerah) yang bertugas khusus untuk menangani dan menanggulangi terjadinya bencana. Disisi lain regulasi yang mengatur pengelolaan bencana masih belum sepenuhnya diterapkan oleh lembaga terkait, pihak swasta maupun masyarakat.

\section{METODE}

Rumusan masalah dalam kajian ini adalah bagaimana kondisi kelembagaan dalam penanggulangan bencana serta regulasi penanggulangan bencana di Kabupaten Kediri. Sedangkan tujuan dalam kajian ini adalah untuk mengetahui kondisi kelembagaan dalam penanggulangan bencana serta regulasi penanggulangan bencana di Kabupaten Kediri.

Ruang lingkup dari Kajian Kelembagaan dan Regulasi Penanggulangan Bencana di Kabupaten Kediri adalah sebagai berikut:

1. Melakukan pengumpulan data, identifikasi data dan analisis data terkait (i) kondisi existing kelembagaan penanggulangan bencana di Kabupaten Kediri

2. Melakukan identifikasi dan analisis terhadap persoalan utama yang dihadapi terkait kondisi existing kelembagaan penanggulangan bencana dan regulasi Penanggulangan Bencana di Kabupaten Kediri

3. Melakukan analisis data guna merumuskan hal-hal yang diperlukan di masa mendatang dalam rangka mengatasi persoalan utama terkait dengan kelembagaan dan regulasi Penenggulangan Bencana, guna menyusun rekomendasi .

\section{HASIL DAN PEMBAHASAN}

Hasil pemetaan yang dilakukan Pemerintah Kabuapten (Pemkab) Kediri diketahui terdapat delapan wilayah yang rawan bencana tanah longsor dan banjir, diantaranya Kecamatan Mojo, Semen, Banyakan, Grogol, Tarokan, Kepung, Puncu serta Kecamatan Kandangan. Wilayah yang masuk zona rawan tersebut umumnya berada di kawasan pinggiran atau sekitar lereng gunung. Selain ancaman dari gunung kelud, wilayah kabupaten Kediri juga cukup banyak dalam kondisi rawan bencana banjir dan longsor, seperti pada bulan Februari 2015 terjadi bencana banjir bandang longsor di desa-desa di lereng gunung wilis diantaranya desa Bulu, Blimbing, Petungroto, Maesan, Kraton, Tambibendo, Keniten, Surat, dan Jugo.

Memiliki daerah yang rawan akan bencana, ternyata Kabupaten Kediri hingga akhir tahun 2014 belum memiliki BPBD (Badan Penanggulangan Bencana Daerah) yang bertugas khusus untuk menangani dan menanggulangi terjadinya bencana. Data BPBD Propinsi Jawa Timur, Kabupaten Kediri tercatat masih memiliki Satuan Pelaksana Penanggulangan Bencana (Satlak PB) yang seharusnya sesuai amanat UU Nomer 24 tahun 2007 Satlak PB mulai tahun 2008 sudah diganti dengan BPBD (Badan Penanggulangan Bencana Daerah). Akibat dari belum adanya BPBD di Kabupaten Kediri pada saat itu, salah satu diantaranya dirasakan pada waktu terjadinya Erupsi Gunung Kelud pada beberapa waktu lalu.

Kabupaten Kediri merupakan kabupaten yang paling terakhir di Provinsi Jawa Timur yang baru membentuk Badan Penanggulangan Bencana Daerah (BPBD). Dasar hukum pembentukan BPBD Kabupaten Kediri adalah 1) Peraturan Daerah Kabupaten Kediri Nomor 2 Tahun 2015 tentang Organisasi dan Tata Kerja Badan Penanggulangan Bencana Daerah yang diundangkan pada tanggal 2 Februari 2015 dan 2) Peraturan Bupati Kediri Nomor 5 Tahun 2015 tentang Penjabaran Tugas dan Fungsi Badan Penanggulangan Bencana Daerah yang diundangkan pada tanggal 3 Februari 2015.

Dalam Peraturan Daerah Kabupaten Kediri Nomor 2 tahun 2015 dan Peraturan Bupati Kabupaten Kediri Nomor 5 tahun 2015 diuraikan bahwa susunan organisasi BPBD Kabupaten Kediri terdiri dari :

1. Kepala, berkedudukan dibawah dan bertanggung jawab kepada Bupati yang dijabat secara ex-officio oleh Sekretaris Daerah;

2. Unsur Pengarah, berada dibawah dan bertanggungjawab langsung kepad Kepala BPBD, pengaturan unsur pengarah BPBD ditetapkan sesuai dengan peraturan perundang-undangan; dan

3. Unsur Pelaksana, berkedudukan dibawah dan bertanggung jawab kepada Kepala BPBD yang 
dipimpin oleh Kepala Pelaksana yang membantu Kepala BPBD dalam penyelenggaraan tugas dan fungsi BPBD.

Susunan Organisasi Unsur Pelaksana BPBD adalah sebagai berikut:

1. Kepala Pelaksana;

2. Sekretariat;

3. Seksi Pencegahan dan Kesiapsiagaan;

4. Seksi Kedaruratan dan logistik;

5. Seksi Rehabilitasi dan Rekonstruksi;

6. Kelompok Jabatan Fungsional.

Dalam menjalankan tugas dan fungsinya, BPBD tidak bekerja secara individu, melainkan berkoordinasi juga dengan institusi terkait lainnya, baik institusi pemerintah ataupun non-pemerintah.

Persoalan Utama Kelembagaan dan Regulasi Penanggulangan Bencana yang dihadapi Pemerintah Kabupaten Kediri. Kondisi spesifik tersebut adalah : (1) Pada saat penelitian ini dilakukan, Kabupaten Kediri baru saja menghadapi sebuah peristiwa bencana yang relatif besar, yaitu bencana erupsi gunung Kelud; memang dampak erupsi Gunung Kelud tidak hanya ke wilayah Kaupaten Kediri, akan tetapi juga ke kabupaten/Kota yang lain, misalnya Kabupaten Malang, Kota Blitar, bahkan sampai ke Yogyakarta; namun secara moral beban Pemerintah Kabupaten Kediri amat besar mengingat sebelum erupsi Gunung Kelud terjadi, baru saja ada Surat Keputusan Gubernur yang melegitimasi bahwa Gunung Kelud berkedudukan di Kabupaten Kediri; (2) padaa saat penelitian ini dilakukan, BPBD Kabupaten Kediri. baru saja dibentuk, dan pejabatnya baru dilantik pada tanggal 10 Februari 2015; artinya pada saat terjadinya bencana erupsi gunung Kelud, BPBD secara resmi belum terbentuk, dan saat ini BPBD menjadi sebuah lembaga baru.

Masalah kelembagaan dan regulasi penanggulangan bencana yang dihadapi oleh Pemerintah Kabupaten Kediri, sebagai berikut :

1. BPBD Kabupaten Kediri pada saat ini menjadi lembaga baru; oleh karena pelantikanpara pejabatnya baru berlangsung pada bulan Februari 2015, maka BPBD belum memiliki alokasi anggaran di APBD 2015. Akibatnya lembaga ini belum dapat melaksanakan tugas pokok dan fungsi sebagaimana mestinya. Sejumlah sarana dan prasarana, misalnya gedung, mebelair, serta peralatan perkantoran juga belum tersedia. Saat ini disediakan sebuah ruang darurat yang difungsikan sebagai sekretariat operasional BPBD; dengan didukung oleh 11 orang personal.

2. Pemerintah Kabupaten Kediri belum menyusun sejumlah dokumen regulasi dan dokumen kebijakan Perencanaan Penanggulangan Bencana yang secara kelembagaan menjadi kewajibannya. Maka sejumlah dokumen yang perlu dsusun dalam waktu dekat mestinya adalah :
a. Peraturan Daerah tentang Penanggulangan Bencana
b. Peraturan Bupati sebagai turunan dari Peraturan Daerah
c. Rencana StrategisPenanggulangan Bencana
d. Rencana Penanggulangan Bencana
e. Rencana Aksi Penanggulangan Bencana
f. Beberapa SOP yang diperlukan

3. Melengkapi berfungsinya kelembagaan Penanggulangan Bencana, perlu dibentuk Forum Pengurangan Risiko Bencana, sebagai media komunikasi dan koordinasi Antara Pemerintah/Pemerintah Daerah, Dunia Usaha dan masyarakat.

4. Pada saat ini sedang disusun rencana Program Pedampingan Pengembangan Ekonomi Masyarakat di Daerah terdampak erupsi gunung Kelud dan Rencana Pendampingan Penyusunan Rencana Strategis yang didukung dananya oleh BNPB dan lembaga donor. Pengalaman yang dapat dipetik dari Kabupaten Kediri adalah : ketika lembaga yang khusus menangani Penanggulangan Bencana, yaitu BPBD belum terbentuk, terjadi peristiwa bencana yang relatif besar yaitu erupsi gunung Kelud. Implikasi ketidakberadaan lembaga tersebut saat menghadapi keadaan darurat bencana adalah:
a. Tidak terdapat lembaga yang menjalankan fungsi komando, koordinasi, dan fasilitasi.
b. Bantuan tidak semuanya dapat terserap
c. Ada kesulitan dalam menyusun pertanggungjawaban keuangan
d. Dan sejumlah implikasi negative yang lain

5. Pada pasca erupsi gunung Kelud, masyarakat yang terdampak bencana mengajukan sejumlah tuntutan (ada 9 tuntutan), salah satu dari 9 tuntutan masyarakat itu adalah : "Pemerintah Kabupaten Kediri secepatnya harap membentuk Badan Penanggulangan Daerah (BPBD)".

\section{PENUTUP}

\section{Simpulan}

Kabupaten kediri merupakan salah satu kabupaten di Jawa Timur yang memiliki potensi terjadinya bencana alam, dan yang lebih menarik ternyata Kabupaten Kediri hingga akhir tahun 2014 belum memiliki BPBD (Badan Penanggulangan Bencana Daerah) yang bertugas khusus untuk menangani dan menanggulangi terjadinya bencana. 
Kabupaten Kediri merupakan kabupaten yang paling terakhir di Provinsi Jawa Timur yang baru membentuk Badan Penanggulangan Bencana Daerah (BPBD). Dasar hukum pembentukan BPBD Kabupaten Kediri adalah 1) Peraturan Daerah Kabupaten Kediri Nomor 2 Tahun 2015 tentang Organisasi dan Tata Kerja Badan Penanggulangan Bencana Daerah yang diundangkan pada tanggal 2 Februari 2015 dan 2) Peraturan Bupati Kediri Nomor 5 Tahun 2015 tentang Penjabaran Tugas dan Fungsi Badan Penanggulangan Bencana Daerah yang diundangkan pada tanggal 3 Februari 2015. Perlunya dibentuk Forum Pengurangan Risiko Bencana, sebagai media komunikasi dan koordinasi Antara Pemerintah/Pemerintah Daerah, Dunia Usaha dan masyarakat..

\section{Saran}

1. Kabupaten Kediri segera memebentuk/memiliki BPBD (Badan Penanggulangan Bencana Daerah) yang bertugas khusus untuk menangani dan menanggulangi terjadinya bencana.

2. Adanya Forum yang khusus menelaah Pengurangan Risiko Bencana, sebagai media komunikasi dan koordinasi Antara Pemerintah/Pemerintah Daerah, Dunia Usaha dan masyarakat.

3. Perlunya memberikan kesadaran serta sosialisasi kepada masyarakat terhadap tanggap bencana sehingga siap apabila sewaktu waktu terjadi musibah/bencana yang tidak terduga.

\section{DAFTAR PUSTAKA}

Arnold T. 2014, Bencana Skala Besar atau Kecil adalah Bencana, dalam http://utama.seruu.com/read/2014/02/05/202166/form ama-bencana-skala-besar-atau-kecil-adalah-bencana.

Badan Nasional Penanggulangan Bencana (BNPB), 2014, Data Kejadian Bencana Tahun 2014, Jakarta.

Badan Penanggulangan Bencana Daerah (BPBD) Provinsi Jawa Timur, 2009, Rencana Strategis Penanggulangan Bencana 2009-2014, Dokumen BPBD Jawa Timur, Surabaya.

Badan Perencanaan Pembangunan Nasional (Bappenas), 2010, Rencana Nasional Pengurangan Risiko Bencana 2010-2014, Jakarta.

Badan Pusat Statistik, 2014, Statistik Indonesia 2013, Jakarta.

Haryati, E, 2013, Materi Sosialisasi Peraturan Daerah Nmor 3 Tahun 3010 tentang Penanggulangan Bencana di Provinsi Jawa Timur, diselenggarakan oleh DPRD Provinsi Jawa Timur.
Meyer, Robert. R, dkk (1980), Rancangan Penelitian Kebijakan Sosial, Pustekom Dikbud \& CV Rajawali, Jakarta.

Miles B. Mathew dan A. Michall Huberman. (1992), Analisa Data Kualitatif, Penerbit Universitas Indonesia (UI-Press), Jakarta.

Parsons, Wayne, 2006, Public Policy (Pengantar Teori dan Praktek Analisis Kebijakan), Kencana Prenada Media Group, Jakarta.

Peraturan Menteri Dalam Negeri Nomor 46 Tahun 2008 tentang Pedoman Organisasi dan Tata Kerja Badan Penanggulangan Bencana Daerah.

Peraturan Badan Nasional Penanggulangan Bencana Nomor 3 Tahun 2008 tentang Pedoman Pembentukan Badan Penanggulangan Bencana Daerah.

Peraturan Kepala Badan Nasional Penanggulangan Bencana Nomor 3 Tahun 2008 tentang Pedoman Pembentukan Badan Penanggulangan Bencana Daerah.

Peraturan Kepala Badan Nasional Penanggulangan Bencana Nomor 4 Tahun 2008 tentang Pedoman Penyusunan Rencana Penanggulangan Bencana.

Peraturan Daerah Provinsi Jawa Timur Nomor 3 Tahun 2010 tentang Penanggulangan Bencana di Provinsi Jawa Timur.

Peraturan Daerah Provinsi Jawa Timur Nomor 2 Tahun 2009 tentang Organisasi dan Tata Kerja Lembaga Lain Provinsi Jawa Timur.

Peraturan Gubernur Provinsi Jawa Timur No 27 Tahun 2009 tentang Uraian Tugas Sekretariat, Bidang, Sub Bagian Dan Seksi Badan Penanggulangan Bencana Daerah Provinsi Jawa Timur.

Peraturan Daerah Kabupaten Kediri Nomor 2 Tahun 2015 tentang Organisasi dan Tata Kerja Badan Penanggulangan Bencana Daerah.

Peraturan Bupati Kediri Nomor 5 Tahun 2015 tentang Penjabaran Tugas dan Fungsi Badan Penanggulangan Bencana Daerah..

Sudarmawan, 2014, Materi Pelatihan Jurnalis Siaga Bencana, dokumenBadan Penanggulagan Bencana Daerah (BPBD) Provinsi Jawa Timur, Surabaya, Kamis 17 April 2014.

Sugiono, 2003. Metode Penelitian Administrasi, Alfa Beta, Bandung

Syamsul Maarif, 2012, Materi Peningkatan Kapasitas Aparatur Badan Penanggulangan Bencana Daerah( BPBD) Provinsi Jawa Timur, Dokumen BPBD ProvinsiJawa Timur, Surabaya.

Undang-Undang Repubik Indonesia Nomor 24 Tahun 2007 tentang Penanggulangan Bencana. 
Van Meter, D.S and C.E Van Horn., 1975. The Policy Implementation Process : A Conceptual Framework, Administration and Society

Wahab. Solichin, Abdul, 1997. Analisis Kebijakan: Dari Formulasi ke Implementasi Kebijakan Negara, Malang

Wiranto. S, 2010, Konsep Pemanfaatan Injasmar Guna Penangulangan Bencana Alam Dalam Rangka Pertahanan Negara Dari Ancaman Nonmiliter, Pedoman Penanganan Penanggulangan Bencana bagi TNI AL. 